\title{
An efficient and cost-effective method for DNA extraction from athalassohaline soil using a newly formulated cell extraction buffer
}

\author{
Avinash Narayan $^{1} \cdot$ Kunal Jain $^{1} \cdot$ Amita R. Shah $^{1} \cdot$ Datta Madamwar $^{1}$
}

Received: 29 June 2015/ Accepted: 28 October 2015/Published online: 13 February 2016

(c) The Author(s) 2016. This article is published with open access at Springerlink.com

\begin{abstract}
The present study describes the rapid and efficient indirect lysis method for environmental DNA extraction from athalassohaline soil by newly formulated cell extraction buffer. The available methods are mostly based on direct lysis which leads to DNA shearing and coextraction of extra cellular DNA that influences the community and functional analysis. Moreover, during extraction of DNA by direct lysis from athalassohaline soil, it was observed that, upon addition of poly ethylene glycol (PEG), isopropanol or absolute ethanol for precipitation of DNA, salt precipitates out and affecting DNA yield significantly. Therefore, indirect lysis method was optimized for extraction of environmental DNA from such soil containing high salts and low microbial biomass (CFU $4.3 \times 10^{4}$ per gram soil) using newly formulated cell extraction buffer in combination with low and high speed centrifugation. The cell extraction buffer composition and its concentration were optimized and PEG $8000(1 \%$; w/v) and $1 \mathrm{M} \mathrm{NaCl}$ gave maximum cell mass for DNA
\end{abstract}

Electronic supplementary material The online version of this article (doi:10.1007/s13205-016-0383-0) contains supplementary material, which is available to authorized users.

Datta Madamwar

datta_madamwar@yahoo.com

Avinash Narayan

avinas.narayan@gmail.com

Kunal Jain

qnal.jain@gmail.com

Amita R. Shah

arshah02@yahoo.co

1 BRD School of Biosciences, Sardar Patel University, Vadtal Road, Satellite Campus, Bakrol 388 315, Anand, Gujarat, India extraction. The cell extraction efficiency was assessed with acridine orange staining of soil samples before and after cell extraction. The efficiency, reproducibility and purity of extracted DNA by newly developed procedure were compared with previously recognized methods and kits having different protocols including indirect lysis. The extracted environmental DNA showed better yield (5.6 \pm $0.7 \mu \mathrm{g} \mathrm{g}^{-1}$ ) along with high purity ratios. The purity of DNA was validated by assessing its usability in various molecular techniques like restriction enzyme digestion, amplification of 16S rRNA gene using PCR and UV-Visible spectroscopy analysis.

Keywords Environmental DNA · Saline desert soil · DNA extraction $\cdot$ Athalassohaline $\cdot$ Microbial cell extraction

\section{Introduction}

The molecular analysis of community DNA is the ultimate route to study the diversity of microbial wealth and genetic variation in natural conditions, to recover novel genes for understanding their metabolic functions, to track metabolic pathways and genetic adaptations for surviving under various environmental conditions (Kakirde et al. 2010; Delmont et al. 2012; Qu et al. 2009; Cary et al. 2010; Sharma et al. 2014). Subsequently, extraction of highly pure and unbiased environmental DNA is very fundamental and significant process. It requires basic understanding of physicochemical properties of soil (viz. organic content, presence of metal ions, salts, etc.) that always hinders the effectiveness of various treatment procedures and chemicals used during DNA extraction, which inturn affects the quality and quantity of extracted environmental DNA 
(Lombard et al. 2011; Young et al. 2014). Moreover, every environmental sample has its own set of physicochemical composition and biomass abundance. Therefore, every type of soil needs protocol optimization for environmental DNA extraction.

Many studies have demonstrated the extraction of environmental DNA from different types of environments. Various approaches like direct lysis, freeze-thaw lysis (Herrick et al. 1993), bead beating (Miller et al. 1999; Courtois et al. 2001; Petric et al. 2011; Urakawa et al. 2010), liquid nitrogen grinding (Ranjard et al. 1998), ultrasonication (Picard et al. 1992), hot detergent treatment (Holben 1994), use of strong chaotropic agents like guanidinium salts (Porteous et al. 1997), and high concentration of lysozyme treatment (Hilger and Myrold 1991) have been applied for environmental DNA extraction. Generally, the direct lysis method is believed to cause DNA shearing and also fails to remove impurities including humic acid, fulvic acid, metal ions and salts, the major interfering agents in molecular analysis. Therefore, it needs additional purification step, which ultimately lowers the DNA yield. Moreover, the biasness and shearing effect due to direct lysis method limit the use of environmental DNA in large insert-based library preparation and also its use on the next generation sequencing platform. Therefore, developing an indirect lysis method is the utmost requirement for metagenomics-mediated community analysis. Many reports clearly describe the advantages of indirect methods over direct lysis method (Zapata et al. 2010; Qiao et al. 2013; Delmont et al. 2011). Since microbial cell extraction is the key step of the indirect lysis method, the formulation of extraction buffer and the primary need to establish indirect lysis-based DNA extraction protocol are highly imperative.

In the present study, we have demonstrated an indirect lysis-based DNA extraction method by formulating PEG$\mathrm{NaCl}$-based cell extraction buffer with a promising efficiency of microbial cell extraction/recovery from athalassohaline soil samples. PEG is amphiphilic in nature, which thought to interact with cells and it was observed that cell wall absorbs high amounts of PEG that may be responsible for cell dissociation from soil particles. The success of the protocol was verified by comparing the quality and quantity of extracted environmental DNA with that of three commercially available DNA extraction kits namely NucleoSpin Soil, ZR soil Microbe DNA (both kits are based on direct lysis) and XcelGen Soil gDNA Isolation kit (based on indirect lysis), and three widely used DNA extraction methods, beat beating method (Miller et al. 1999), hot detergent lysis method (Desai and Madamwar 2006) and indirect lysis method employing high concentration of lysozyme with hot detergent lysis (Gabor et al. 2003).

\section{Materials and methods}

\section{Soil sampling}

Subsurface $(8-10 \mathrm{~cm})$ soil core samples were collected from four distinct sites from Great Rann of Kachchh, Gujarat, India, designated as: BOP-Dharamshala $\left(24^{\circ} 2^{\prime} 4^{\prime \prime} \mathrm{N}, \quad 69^{\circ} 39^{\prime} 46^{\prime \prime} \mathrm{E}\right)$, India Bridge $\left(23^{\circ} 59^{\prime} 13^{\prime \prime} \mathrm{N}\right.$, $\left.69^{\circ} 44^{\prime} 41^{\prime \prime} \mathrm{E}\right)$; Near India Bridge $\left(23^{\circ} 59^{\prime} 35^{\prime \prime} \mathrm{N}, 69^{\circ} 42^{\prime} 12^{\prime \prime} \mathrm{E}\right)$ and Vighakot $\left(24^{\circ} 13^{\prime} 1^{\prime \prime} \mathrm{N}, 69^{\circ} 11^{\prime} 51^{\prime \prime} \mathrm{E}\right)$. Soils were sieved ( $\sim 2 \mathrm{~mm}$ poresize) for removing coarse particles and other debris and plant roots. The sieved soil samples were stored at $4{ }^{\circ} \mathrm{C}$ under dark conditions. Soil characteristics were determined through standard methods.

\section{Buffers}

Cell extraction buffer: $1 \%$ (w/v) PEG 8000, $1 \mathrm{M} \mathrm{NaCl}, \mathrm{pH}$ of the buffer was adjusted to $\mathrm{pH} 9.2$, using $0.2 \mathrm{~N} \mathrm{NaOH}$.

Suspension buffer: $10 \%$ Sucrose, $10 \mathrm{mM}$ Tris- $\mathrm{Cl}$ (pH 8.0), 50 mM EDTA (pH 8.0), $50 \mathrm{nM} \mathrm{NaCl}$.

TE buffer: $10 \mathrm{mM}$ Tris (pH 8.0); 1 mM EDTA (pH 8.0).

\section{Extraction of microbial cells}

Five hundred milligrams of soil from each site were suspended in $50 \mathrm{ml}$ of newly formulated cell extraction buffer. The soil suspension was continuously mixed for $3 \mathrm{~min}$ at $25{ }^{\circ} \mathrm{C}$ on tube rotator (SLM-TR-100, Bangalore GeNei) with the speed of $16 \mathrm{rpm}$. This homogenous mixture was centrifuged at lower speed of $220 \times g$ for $5 \mathrm{~min}$ at $25^{\circ} \mathrm{C}$. The first centrifugation step at lower speed is essential to retain cell mass in supernatant and to pellet other soil particles to prevent them for co-extraction with cell pellet. The cell mass was harvested at comparatively higher speed of $6500 \times \mathrm{g}$ for $20 \mathrm{~min}$ at $25^{\circ} \mathrm{C}$. The obtained cell mass was resuspended in $500 \mu \mathrm{l}$ of sterile suspension buffer.

\section{Acridine orange staining for cell extraction efficiency determination}

The efficiency of cell extraction was determined by acridine orange staining $(0.1 \%$; w/v, filter sterilized). Each soil samples before and after cell extraction was visualized under an epifluorescence microscope (BX41, Olympus) and cell count for both the sample was measured by manual counting of the fluorescence dots.

\section{Cell lysis, DNA extraction and purification}

DNA was extracted by two-step cell lysis by a combination of chemical, (enzymatic lysis and hot detergent lysis) and 
physical (bead beating) methods. Initially cell mass was lysed by adding $50 \mu \mathrm{l}$ of freshly prepared lysozyme $\left(20 \mathrm{mg} \mathrm{ml}^{-1}\right.$ ) and incubated at $37^{\circ} \mathrm{C}$ for $45 \mathrm{~min}$ under shaking conditions followed by Proteinase $\mathrm{K}$ treatment $\left(12.5 \mu \mathrm{l}, 20 \mathrm{mg} \mathrm{ml}^{-1}\right)$ at $55{ }^{\circ} \mathrm{C}$ for $45 \mathrm{~min}$. The resultant cell lysate was further lysed by SDS treatment $(50 \mu \mathrm{l}$, $20 \%$; w/v) at $65{ }^{\circ} \mathrm{C}$ for 45 min with intermittent mixing at every $5 \mathrm{~min}$ interval. The cell lysate was centrifuged at $11,000 \times g$ for $3 \mathrm{~min}$ at $20^{\circ} \mathrm{C}$; supernatant (S1) was collected and the pellet was resuspended in suspension buffer (200 $\mu \mathrm{l})$ alongwith $20 \%$ SDS $(50 \mu \mathrm{l})$ and $\sim 500 \mathrm{mg}$ sterile glass beads $(1-1.5 \mathrm{~mm})$ and vortexed at maximum speed for $3 \mathrm{~min}$. The lysate was again centrifuged at $11,000 \times g$ for $3 \mathrm{~min}$ at $20{ }^{\circ} \mathrm{C}$ to pellet down cell debris and supernatant (S2) was mixed with $\mathrm{S} 1$ and subjected for RNase A (10 $\mu \mathrm{l}$ of $\left.10 \mathrm{mg} \mathrm{ml}^{-1}, 37^{\circ} \mathrm{C}, 15 \mathrm{~min}\right)$ treatment. Cellular proteins and other cell debris were precipitated through 0.35 th volume $2.5 \mathrm{M}$ potassium acetate $(\mathrm{pH} 8.0)$. The precipitate was removed by combination of two-step centrifugation of low $\left(6500 \times \mathrm{g}, 20^{\circ} \mathrm{C}, 3 \mathrm{~min}\right)$ and high $\left(8000 \times g, 20^{\circ} \mathrm{C}, 3 \mathrm{~min}\right)$ speed. Metagenomic DNA was precipitated from the aqueous phase by adding equal volume of isopropanol and incubated for 5 min under ambient conditions and DNA precipitate was pelleted at $11,000 \times g$, at $4{ }^{\circ} \mathrm{C}$ for $20 \mathrm{~min}$. DNA pellet was washed twice with freshly prepared $70 \%$ ethanol, dried at $55^{\circ} \mathrm{C}$ for $10 \mathrm{~min}$ and resuspended in $50 \mu \mathrm{l}$ nuclease free TE buffer and stored at $-20{ }^{\circ} \mathrm{C}$ till further use.

\section{DNA quantification, purity and spectroscopic analysis}

Extracted DNA was quantified on Nanodorp spectrophotometer (Implen $\mathrm{GmbH}$, Germany) and its purity was expressed as ratios of absorption at $\mathrm{A}_{260} / \mathrm{A}_{280}$ and $\mathrm{A}_{260} /$ $\mathrm{A}_{230}$. Moreover, the diluted (1:10 in TE buffer) DNA samples analyzed over 230-260 nm using UV-Visible spectrophotometer (Specord 210, Analytik Jena AG, Jena, Germany).

\section{S rRNA gene amplification}

The above DNA extraction method was validated by accessing its purity and amenability for further molecular analysis by amplifying 16S rRNA gene through polymerase chain reaction (PCR). The extracted DNA was used as a template $(\sim 50 \mathrm{ng})$ in a $30 \mu \mathrm{l}$ reaction system containing $1 \mathrm{X}$ reaction buffer $(10 \mathrm{mM}$ Tris-Cl, $\mathrm{pH} 9.0$, $15 \mathrm{mM} \mathrm{MgCl} 2,0.1 \%$ Triton X-100), $0.30 \mathrm{mM}$ of each dNTPs, 0.60 pmol of each universal primers $8 \mathrm{~F}$ ( $5^{\prime}$-AGA GTT TGA TCC TGG CTC AG- $\left.3^{\prime}\right)$ and 1492R (5'-GGT TAC CTT GTT ACG ACT- $3^{\prime}$ ) and 1.5 units of Taq DNA polymerase. $16 \mathrm{~S}$ rRNA gene was amplified through initial denaturation at $94{ }^{\circ} \mathrm{C}$ for $4 \mathrm{~min}$, followed by 30 cycles of denaturation at $94{ }^{\circ} \mathrm{C}$ for $1 \mathrm{~min}$, primers annealing at $54{ }^{\circ} \mathrm{C}$ for $1 \mathrm{~min}$ and extension at $72{ }^{\circ} \mathrm{C}$ for $1 \mathrm{~min}$ and final extension at $72{ }^{\circ} \mathrm{C}$ for $5 \mathrm{~min}$. Gene amplification was observed by electrophoresis of amplified products on $1.2 \%$ agarose in $1 \mathrm{X}$ TAE buffer [ $40 \mathrm{mM}$ Tris acetate, $1 \mathrm{mM}$ EDTA (pH 8.0)].

\section{Comparison of DNA extraction method}

The efficiency of newly developed environmental DNA extraction method was compared with extraction from same soil samples with three commercially available kits (a) NucleoSpin ${ }^{\circledR}$ Soil (Macherely-Nagel GmbH, Germany), (b) ZR Soil Microbe DNA MiniPrep (Zymo Research, USA) and (c) XcelGen Soil gDNA isolation (based on indirect lysis) (Xcelris Genomics, India) and three widely used manual protocols (d) hot detergent lysis and column purification (Desai and Madamwar 2006), (e) bead beating lysis (Miller et al. 1999) and (f) high concentration of lysozyme/hot detergent lysis (Indirect lysis method) (Gabor et al. 2003). Environmental DNA extracted by above methods was compared with that of newly developed method in terms of purity, yield and quality by using UVVisible spectroscopy, restriction enzyme digestion, and polymerase chain reaction amenability.

\section{Results and discussion}

\section{Soil characteristics}

Results from Table S1 revealed the saline nature of the soils of Rann of Kachchh with average electrical conductivity of $2.02 \mu \mathrm{S} \mathrm{cm}^{-1}$ and measured salinity at the level of 8.85 ppt. Soil evidently contains comparatively high amount of metal ions and salts viz, calcium $262 \mathrm{mg} \mathrm{kg}^{-1}$, magnesium $126.6 \mathrm{mg} \mathrm{kg}^{-1}$, sodium $163 \mathrm{mg} \mathrm{kg}^{-1}$, chloride $311 \mathrm{mg} \mathrm{kg}^{-1}$, etc. It is understood that metal ions and salts have a tendency to bind DNA and cell surface receptors, thereby preventing direct DNA extraction from such soils and it co-precipitates along with DNA as DNA-salt complex, which in turn inhibits down stream DNA processing. However, Eichhorn and Shin (1968) observed that the negatively charged DNA strands tend to unwind in the absence of counter ions.

\section{Microbial cell extraction and extraction efficiency}

Since the present DNA extraction method was primarily based on cell extraction, the composition of cell extraction buffer plays an important role for obtaining better DNA yield. Cell extraction from saline soil by newly formulated 

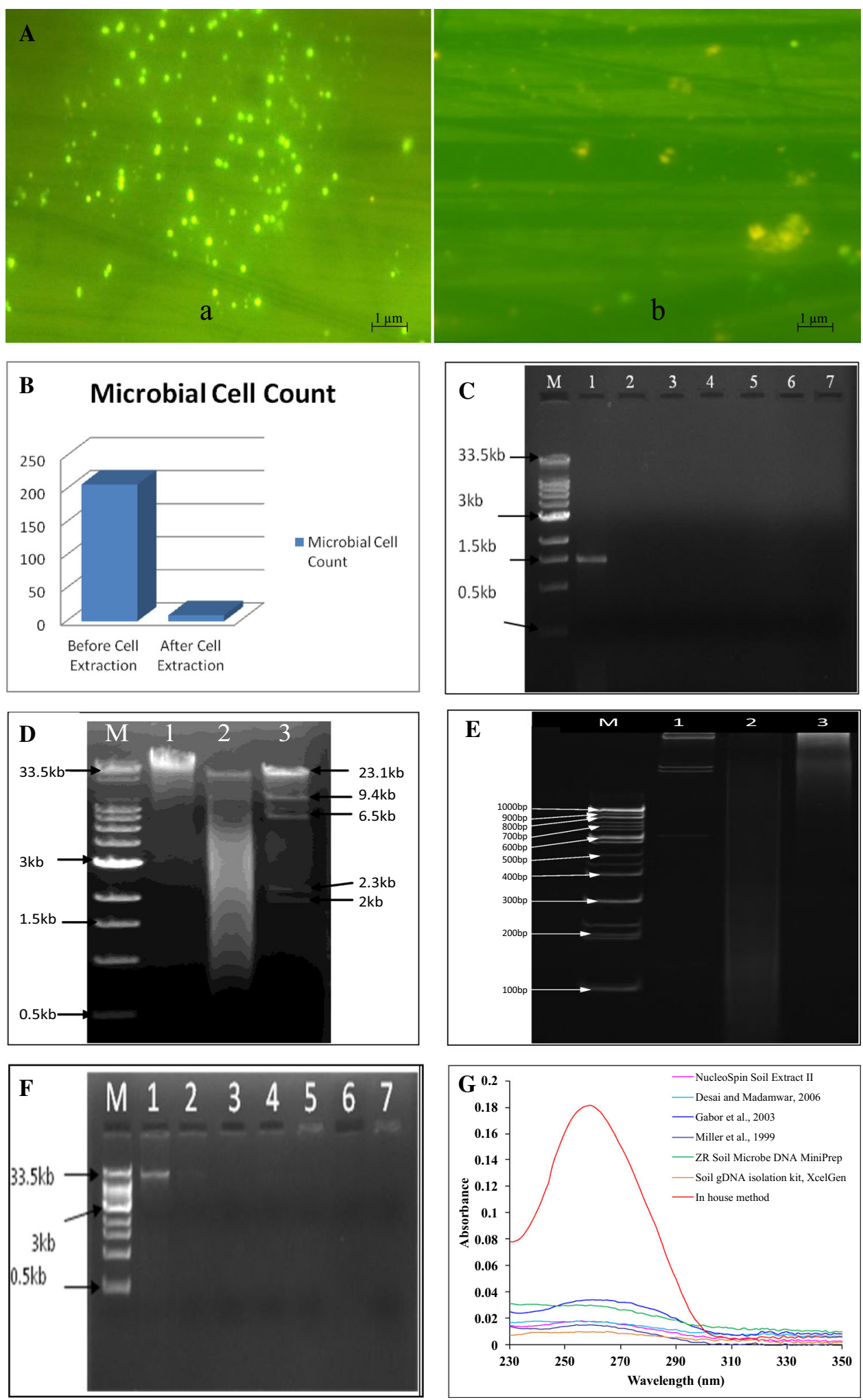
4Fig. 1 A Epifluorescence microscopic images of acridine orange stained slides, $(a)$ intact soil sample and $(b)$ soil sample after cell extraction. B Acridine orange staining-based microbial cell count by epifluoresence microscopy before and after cell extraction. C Electrophoresed $1 \%$ gel showing amplified $16 \mathrm{~S}$ rRNA gene, $M$ molecular weight marker, lane 1: amplified 16S rRNA gene from environmental DNA extracted by newly developed method, lane 2-7: amplification of $16 \mathrm{~S}$ rRNA gene from DNA extracted by published methods and kits, (it can be observed that DNA was unable to amplify by these methods). D Electrophoresed $1 \%$ agarose gel showing, lane $M$ : SuperMix DNA ladder $(0.5 \mathrm{~kb}$ to $33 \mathrm{~kb})$, lane 1 : environmental DNA, lane 2: mixture of environmental DNA extracted from newly developed method and $\lambda$ DNA digested with Hind III, lane 3: $\lambda$ DNA digested with Hind III and. E Polyacrylamide gel (9\%) showing: lane $M$ molecular weight marker $100 \mathrm{bp}$, lane 2: $\lambda$ DNA digested using Hind III, lane 3: completely digested environmental DNA extracted with newly developed method with Hae III (10 h), and lane 4: partially digested environmental DNA extracted with newly developed method with Hae III (1 h). F Electrophoresed $1 \%$ agarose gel showing DNA marker and extracted environmental DNA by various methods. $M$ denotes molecular weight marker, lane 1 : showing environmental DNA extracted by newly developed method, lane 2: high concentration of lysozyme lysis method (Gabor et al. 2003), lane 3: hot detergent lysis method (Desai and Madamwar 2006), lane 4: bead beating lane (Miller et al. 1999) 5: NucleoSpin Soil Extract II, lane 6: Soil gDNA isolation kit (XcelGen), lane 7: ZR Soil Microbe DNA MiniPrep. G UV-visible absorbance spectra of environmental DNA extracted by described mentioned methods and kits

and optimized cell extraction buffer showed better DNA yield and maximum DNA purity along with combination of low and high speed centrifugation. PEG 8000 helps in dissociation of cells from soil particles, whereas $\mathrm{NaCl}$ increases the cell stability by preventing osmotic lysis. Moreover, at low speed centrifugation $(220 \times g)$ coarse soil particles were removed and at high speed centrifugation $(6500 \times g)$ cell mass was harvested for DNA extraction.

Figure 1A demonstrates the photographic images of acridine orange staining of the soil before and after cell extraction and Fig. 1B shows comparative account of cell count before and after treatment. The direct count of cell in intact soil and cell extracted soil by epifluorescence microscopy showed that the cell extraction efficiency of the extraction buffer is nearly $95 \%$. The observed results suggested that the cell extraction efficiency was relatively better and higher, on comparing with nycodenz based microbial cell extraction method, extracting only $50 \%$ of the cells (Robe et al. 2002).

\section{DNA quantification and purity}

It was observed that during DNA extraction from saline soils, co-extracted salts and other complex compounds like humic acids are major impurities which not only decrease the total DNA yield but also prevent other in vitro molecular reactions. Results from the Table 1 showed that newly developed indirect DNA extraction method yielded $5.6 \pm 0.7 \mu \mathrm{g}$ of metagenomic DNA per gram of saline soil with purity ratios of 1.820 for $\mathrm{A}_{260} / \mathrm{A}_{280}$ and 1.732 for $\mathrm{A}_{260} / \mathrm{A}_{230}$.

Metagenomic DNA extracted by the method developed by Gabor et al. (2003) also gave good purity ratios; however, DNA yield was very low (Table 1). It was observed that the spectrophotometric measurements for DNA quality assessment with higher values associated with better DNA purity (Psifidi et al. 2015).

The purity level of the extracted DNA was accessed by amplifying 16S rRNA using extracted DNA as template and restriction digestion by Hind III. Figure 1C demonstrates the amplified products of $\sim 1.5 \mathrm{~kb}$ of $16 \mathrm{~S}$ rRNA gene from extracted DNA using newly developed method, while Fig. 1D, E, shows the catalytic breakdown of metagenomic DNA by restriction enzyme Hind III on $1 \%$ agarose and $9 \%$ polyacrylamide gel, respectively. Environmental DNA, extracted by present methods also gave good results when analyzed on the Illumina MiSeq Platform for microbial community structure analysis. Thus, the above results evidently suggested that the efficiency, productivity and level of purity of DNA extracted by newly developed method are significantly higher and it can be used for routine DNA extraction from saline soils.

Table 1 Comparison of purity ratio, DNA yield and PCR amenability of environmental DNA extracted by newly developed method and other recognized methods and commercial kits

\begin{tabular}{lllll}
\hline Method & $\mathrm{A}_{260 / 280}$ & $\mathrm{~A}_{260 / 230}$ & Average DNA yield $\left(\mu \mathrm{g}^{-1}\right)$ & PCR amenability \\
\hline Indirect lysis (newly developed method) & 1.820 & 1.732 & 4.6 & 1.0 \\
Indirect lysis (Gabor et al. 2003) & 1.512 & 0.952 & - & - \\
Direct lysis (Desai and Madamwar 2006) & - & - & - & - \\
Direct lysis (Miller et al. 1999) & - & - & 0.3 & - \\
Direct lysis (NucleoSpin ${ }^{\circledR}$ soil) & 1.657 & 0.714 & 0.5 & - \\
Direct lysis based (ZR soil microbe DNA MiniPrep) & 1.500 & 0.432 & 0.2 & - \\
Indirect lysis based (XcelGen soil gDNA isolation) & 1.677 & 0.815 & & - \\
\hline
\end{tabular}




\section{Comparison of extraction method}

It was observed from Fig. 1F that DNA extracted from three commercial kits and two protocols developed previously (Miller et al. 1999; Desai and Madamwar 2006) was unable to extract any detectable amount of environmental DNA from soils of Rann of Kachchh. However, very low yield of metagenomic DNA was obtained, but with higher purity ratios (as mentioned in "DNA quantification and purity") by indirect lysis method developed by Gabor et al. (2003). Figure $1 G$ demonstrates the overlay graph of absorbance between 230 and $350 \mathrm{~nm}$ for the DNA extracted by all six methods. The results clearly revealed the better productivity and efficiency of newly developed protocol over other established methods and commercially available kits.

\section{Conclusion}

The presented protocol was highly efficient for metagenomics DNA extraction athalasohaline soil. To the best of our knowledge, the study first time demonstrated the use of PEG 8000 in combination of $1 \mathrm{M} \mathrm{NaCl}$ at $\mathrm{pH} 9.2$ for the extraction of microbial cell biomass from the soil. The purified environmental DNA was highly compatible for further molecular analysis like PCR amplification, restriction enzyme digestion and community analysis by next generation sequencing technology.

Acknowledgments Authors are Grateful to Department of Biotechnology (DBT), India for financial support (BT/PR8218/BCE/ 8/1044/2013). They also wish to acknowledge Dr. K. Kartikeyan, Gujarat Institute of Desert Ecology, for help in physicochemical analysis of soil samples.

\section{Compliance with ethical standards}

Conflict of interest The authors declare that they have no conflict of interest.

Open Access This article is distributed under the terms of the Creative Commons Attribution 4.0 International License (http:// creativecommons.org/licenses/by/4.0/), which permits unrestricted use, distribution, and reproduction in any medium, provided you give appropriate credit to the original author(s) and the source, provide a link to the Creative Commons license, and indicate if changes were made.

\section{References}

Cary SC, McDonald IR, Barrett JE, Cowan DA (2010) On the rocks: the microbiology of Antarctic dry valley soils. Nat Rev Microbiol 8:129-138

Courtois S, Frostegard A, Goransson P, Depret G, Jeannin P, Simonet $P$ (2001) Quantification of bacterial subgroups in soil: comparison of DNA extracted directly from soil or from cells previously released by density gradient centrifugation. Environ Microbiol 3:431-439

Delmont TO, Robe P, Clark I, Simonet P, Vogel TM (2011) Metagenomic comparison of direct and indirect soil DNA extraction approaches. J Microbiol Methods 86:397-400

Delmont TO, Prestat E, Keegan KP, Faubladier M, Robe P, Clark IM, Pelletier E, Hirsch PR, Meyer F, Gilbert JA, Paslier DL, Simonet P, Vogal TM (2012) Structure, fluctuation and magnitude of a natural grassland soil metagenome. ISME J 6:1677-1687

Desai C, Madamwar D (2006) Extraction of inhibitor-free metagenomic DNA from polluted sediments, compatible with molecular diversity analysis using adsorption and ion-exchange treatments. Bioresour Technol 98:761-763

Eichhorn GL, Shin YA (1968) Interaction of Metal Ions with Polynucleotides and Related Compounds. XII. The Relative Effect of Various Metal Ions on DNA Helicity. J Am Chem Soc 90:26

Gabor EM, Vries EJD, Janssen DB (2003) Efficient recovery of environmental DNA for expression cloning by indirect extraction method. FEMS Microbiol Ecol 44(2):153-163

Herrick JB, Madsen EL, Batt CA, Ghiorse WC (1993) Polymerase chain reaction amplification of naphthalene-catabolic and $16 \mathrm{~S}$ rRNA gene sequences from indigenous sediment bacteria. Appl Environ Microbiol 59:687-694

Hilger AB, Myrold DD (1991) Method for extraction of Frankia DNA from soil. Agr Ecosyst Environ 34:107-113

Holben WE (1994) Isolation and purification of bacterial DNA from soil. In: Weaver RW et al. (eds.) Methods of soil analysis, Part 2. Microbiological and biochemical properties, vol 5. Soil Science Society of America Inc, Madison, pp 727-751

Kakirde KS, Parsley LC, Liles MR (2010) Size does matter: application-driven approaches for soil metagenomics. Soil Biol Biochem 42(11):1911-1923

Lombard N, Prestat E, Elsas JDV, Simonet P (2011) Soil-specific limitations for access and analysis of soil microbial communities by metagenomics. FEMS Microbiol Ecol 78:31-49

Miller DN, Bryant JE, Madsen EL, Ghiorse WC (1999) Evaluation and optimization of DNA extraction and purification procedures for soil and sediment samples. Appl Environ Microbiol 65:4715-4724

Petric I, Philippot L, Abbate C, Bispo A, Chesnot T, HallinS Lavel K, Lebeau T, Lemanceau P, Leyval C, Lindström K, Pandard P, Romero E, Sarr A, Schloter M, Simonet P, Smalla K, Wilke BM, Laurent FM (2011) Inter-laboratory evolution of the ISO standard 11063 "Soil quality-Method to directly extract DNA from soil samples. J Microbiol Methods 84(3):454-460

Picard C, Ponsonnet C, Paget E, Nesme X, Simonet P (1992) Detection and enumeration of bacteria in soil by direct DNA extraction and polymerase chain reaction. Appl Environ Microbiol 58:2717-2722

Porteous LA, Seidler RJ, Watrud LS (1997) An improved method for purifying DNA from soil for polymerase chain reaction amplification and molecular ecology applications. Mol Ecol 6:787-791

Psifidi A, Dovas CI, Bramis G, Lazou T, Russel CL (2015) Comparison of eleven methods for genomic dna extraction suitable for large-scale whole-genome genotyping and long-term dna banking using blood samples. PLoS One 10(1):e0115960

Qiao JT, Qiu YL, Yuan XZ, Shi XS, Xu XH, Guo RB (2013) Molecular characterization of bacterial and archaeal communities in a full-scale anaerobic reactor treating corn straw. Bioresour Technol 143:512-518

Ranjard L, Poly F, Combrisson J, Richaume A, Nazaret S (1998) A single procedure to recover DNA from the surface or inside aggregates and in various size fractions of soil suitable for PCRbased assays of bacterial communities. Eur J Soil Biol 34:89-97 
Robe P, Nalin R, Capellano C, Vogel TM, Simonet P (2002) Extraction of DNA from soil. Eur J Soil Biol 39(4):183-190

Sharma S, Sharma KK, Kuhad RC (2014) An efficient and economical method for extraction of DNA amenable to biotechnological manipulations, from diverse soils and sediments. J Appl Microbiol 116:923-933

Urakawa H, Habbena WM, Stahl DA (2010) High abundance of ammonia-oxidizing archaea in coastal waters, determined using a modified dna extraction method. Appl Environ Microbiol 76(7):2129-2135
Young JM, Rawlence NJ, Weyrich LS, Cooper A (2014) Limitations and recommendations for successful DNA extraction from forensic soil samples: a review. Sci Justice 54(3):238-244

Zapata IT, Montalvo AG, Ruiz CC, Velazquez R (2010) Generation of large insert metagenomic libraries using indirect DNA extraction method from benthic and ephemeral tropical hypersaline microbial mats, In: Méndez-Vilas A (ed) Current research, technology and education topics in applied microbiology and microbial biotechnology, pp 1569-1575 